selective predation on morphology is rather neglected. It has been known for some time that the intensity of predation may affect both intraspecific and interspecific variation of shell morphology. Some of this variation is very like that produced by environmental differences; indeed it is often a real problem, even in living populations, to disentangle the two. Furthermore, though some of the differences are the result of selection taking place within a generation, some have quite high heritable components. Tevesz and Carter do mention this problem briefly in their chapter on the unionaceans, but it should perhaps have been discussed more fully somewhere.

I noticed only a few examples of laxness in editing. For instance, to give what is essentially the same equation as

$$
\begin{gathered}
L_{t}=L_{\infty}\left(1-\mathrm{e}^{-k t}\right) \\
\quad \text { and } \\
N_{t}=N_{\max }\left(1-c \mathrm{e}^{+r_{0} t}\right)
\end{gathered}
$$

in two different places is needlessly confusing. Also, in my copy (and therefore, presumably, in several hundred others) the pages in the appendices were hopelessly jumbled. This interesting, handsomely produced, well-illustrated book deserves many buyers - but they should all carefully check pages 640 onwards for continuity.

John Currey is a Professor in the Biology Department at the University of York.

\section{SCIENTIFIC BOOKSHOP}

H.K. LEWIS can supply works in all branches of Pure and Applied Science. Catalogues on request. Please state interests.

\section{SCIENTIFIC LENDING LIBRARY}

Annual Subscription from $£ 7.50$. (Available in U.K. only)

Reduced rates for multiple subscriptions.

Prospectus post free on request.

Quarterly List of New Books and new editions added to the Library sent post free to subscribers regularly.
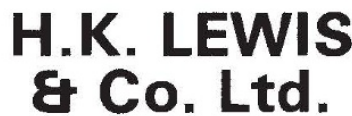

136 GOWER STREET, LONDON, WC1E 6BS

\title{
Historians of science confront the hydra
}

\section{Robert Fox}

The Ferment of Knowledge: Studies in the Historiography of Eighteenth-century Science. Edited by G.S. Rousseau and Roy Porter. Pp. 500. ISBN 0-521-22599-X. (Cambridge University Press: 1980.) £25, $\$ 39.50$.

OVER the past decade, the historiography of eighteenth-century science has been totally recast. In the process, change and complexity have emerged as the leading characteristics of a period which, not so many years ago, was seen as a rather pedestrian interlude between the heady days of the scientific revolution and the expansive age of modern professional science that dawned in the first half of the nineteenth century. The reassessment owes much to the 13 contributors to this absorbing volume of essays. All of them have played a major role, in areas as diverse as industrial science and technology (treated here by Donald Cardwell), the chemical revolution (Maurice Crosland), the life sciences (Jacques Roger), "mathematical cosmography" (the title of Eric Forbes's contribution) and geology (Roy Porter). In The Ferment of Knowledge, however, their brief was to review the state of their particular art and to relate work in their field to larger cultural perspectives. "Strong interpretations" and "coherent analysis" were the objectives of the stock-taking, and it is by these lights that the book must be judged.

What, then, are the "strong interpretations" that emerge, and where are the new beacons? Remarkably, at least one tentative answer to these questions already seems possible. This is because the most obvious historiographical casualty of the 1970 s is the very one that has traditionally dominated studies of science in the age of the Enlightenment: the notion of a unified, transcendent Newtonianism guiding confrontations with nature either as an inspiration or as a target for criticism. John Heilbron's revisionism on this point emerges from his plea for a more detailed study of the practice, as opposed to the metaphysical context, of experimental physics in the eighteenth century: as he observes, the single epithet "Newtonian" is at best unhelpful when applied to a discipline which underwent complete redefinition between the 1720 s and 1800 and which flourished not only in Britain but also in regions of the Continent, notably in Germany, where the writ of Newton barely ran. Simon Schaffer makes even greater play of the conflicting traditions in eighteenth-century natural philosophy: with engaging panache, he argues for an analysis that would see natural philosophy as an autonomous form of discourse informing, and being informed by, the practice of scientific investigation, without ever being part of it. In this way, he may well make better sense not only of the many-headed hydra that scholars of the Newtonian tradition have had to wrestle with but also of anti-Newtonianism of the kind proposed by John Hutchinson in the realm of matter-theory.

Some of the nice problems of interaction raised by Schaffer also appear in Steven Shapin's sophisticated study of the "social uses" of science. In his quest for a "new contextualism", Shapin eschews straightforward notions of interaction between the discrete realms of scientific theory on the one hand and social context on the other. For Shapin, the realms are inseparable, with the result that the content of scientific ideas (and not, for example, merely their diffusion) can only be understood if we also understand the social significance they possessed in the minds of their creators. Such an approach has already yielded a fundamental reinterpretation of Boyle's Christianized corpuscularianism (in the work of J.R. Jacob), and a consideration of differing social uses may also be the key to one of the great conundrums of eighteenth-century historiography: the existence of what appear to have been competing Enlightenments, including both "radical" (the term is Margaret Jacob's) and High Church versions which repudiated Newton's carefully articulated theism.

The Ferment of Knowledge would have been welcome enough if it had merely reviewed a fruitful field of research; the editors and their well-chosen contributors have ensured that it fulfils that task admirably. But the book also says much, by implication, about the state of the history of science as a whole. Time and again, it demonstrates the unprecedented receptiveness of historians of science to work in other disciplines. The techniques of anthropology and modern social history make a welcome appearance (the latter being used to particularly good effect in W.F. Bynum's richly documented paper on medical care). Michael Foucault, too, flits across the stage, though to responses that range from the critically tolerant to the dismissive. The marriage between the history of science and the social sciences would appear to have been fully consummated, to the obvious benefit of a discipline which has striven long and hard to divest itself of an embarrassingly antiquarian past. The aptness of the term "ferment" when applied to recent developments in the history of science needs no underlining.

Robert Fox is Reader in the History of Science at the University of Lancaster and President of the British Society for the History of Science. He is the author of a critical edition of Sadi Carnot's Réflexions sur la puissance motrice du feu (Vrin, Paris: 1978). 